Rev Med (São Paulo) 2002 jan./dez.;81(1/4)i.

\title{
XXI COMU
}

Alguns artigos científicos já demonstraram a importância da iniciação cientifica durante a graduação e suas repercussões na vida profissional do futuro médico: os jovens formados se tornam melhores médicos pois adquirem um espírito crítico, capacidade de selecionar informações relevantes durante o vertiginoso processo de atualização médica, transformando-se até mesmo em líderes regionais.

Carlos da Silva Lacaz, aluno de graduação, presidente do Departamento Científico do Centro Acadêmico Oswaldo Cruz e, mais tarde, grande médico, pesquisador e diretor da Faculdade de Medicina da USP promoveu pela primeira vez, em outubro de 1940, o Congresso dos Estudantes de Medicina, que mais tarde seria o nosso Congresso Médico Universitário (COMU).

O Congresso surgiu da necessidade de se premiar e estimular a produção científica feita pelos acadêmicos. São as palavras de Carlos da Silva Lacaz em um jornal da época: (...) procuramos estimular a nós mesmos. Eles (os congressos) são um complemento necessário à teoria e à prática do ensino, pois proporcionam uma oportunidade a mais para confrontar pesquisas e estudos especializados. $\mathrm{Na}$ época houve cerca de 89 trabalhos científicos a serem julgados e premiados pelos professores.

Assim, valorizando o Congresso estamos direta e indiretamente valorizando a formação do futuro profissional e da ciência médica no Brasil. O Departamento Científico agradece a todos os Professores que, de alguma forma, nos ajudam a realizar esse grande projeto.

\author{
Moisés da Cunha Lima
}

Presidente do XXI Congresso Médico Universitário 